\title{
Determinants of Intra-Industry Trade between Vietnam and Countries in TPP
}

\author{
Ha Minh NGUYEN ${ }^{1}$, Binh Quoc Minh QUAN ${ }^{2}$, Huong Van $\mathrm{LE}^{3}$, Thinh Van TRAN ${ }^{4}$ \\ Received: September 13, 2019 Revised: November 01, 2019 Accepted: November 15, 2019
}

\begin{abstract}
Intra-industry trade (IIT) has played an important role in international trade of Vietnam as a result of rapid growth of the country. This article investigates the level of IIT between Vietnam and 11 trading partners in Trans-Pacific Partnership (TPP) over the period 20002014. Although there have been a large number of empirical researches contributed to the determinants of IIT, most of them only pay attention on developed countries where the trade flows are similar due to similar demand structure and production technology. Until now, there is no study on intra-industry trade between Vietnam and countries in TPP that Vietnam recently signed a trade agreement in early 2016. IIT is measured by the Grubel-Lloyd index. The index shows that the extent of intra-industry trade between Vietnam and the trading countries is not high due to the level of economic development and the market size. The determinants of IIT are examined using a panel regression model. In the empirical analysis, the results indicate that Vietnam's intra-industry trade is positively correlated with country size, while it is negatively correlated with income dissimilarity, the trade openness, and geographical distance. This study contributes to the new theoretical trade theory on the evidence of developing country's IIT.
\end{abstract}

Keywords : Intra-industry Trade, Vietnam, Grubel-Lloyd Index, TPP

JEL Classification Code : F10, F13, F14

\section{Introduction}

The classical theory of international trade suggests that countries should focus on producing goods that they have comparative advantages. However, the commodities mentioned in the theory are belonging to different industries such as rice and textiles. In recent decades, with the deep integration of nations into the global economy, foreign trade between countries becomes more complex and difficult to explain with classical trade theories. The trend of

1 First Author and Corresponding Author, Associate Professor, Ho Chi Minh City Open University, Vietnam. [Postal Address: 97 Vo Van Tan Street, Ward 6, District 3, Ho Chi Minh City 700000, Vietnam] Email: ha.nm@ou.edu.vn

2 Lecturer, Faculty of Economics and Public Management, Ho Chi Minh City Open University, Vietnam. Email: binh.qma@ou.edu.vn

3 People's Committee of Tien Giang Province, Vietnam. Email: huongubtg@gmail.com

4 Ho Chi Minh City Open University, Vietnam. Email: thinh315@yahoo.com

(c) Copyright: Korean Distribution Science Association (KODISA) This is an Open Access article distributed under the terms of the Creative Commons Attribution Non-Commercial License (http://Creativecommons.org/licenses/by-nc/4.0/) which permits unrestricted noncommercial use, distribution, and reproduction in any medium, provided the original work is properly cited. simultaneous import and export of products within the same industry is taking place very quickly. The term "intraindustry trade" has become one of the important terms of the new trade theory that explains most of the current trend in international trade.

There have been many studies on intra-industry trade of countries in the world (Greenaway, Hine, \& Milner, 1994; Zhang \& Clark, 2009). In general, these studies can be categorized into two groups. The first group focuses on explaining the reasons for existence of intra-industry trade (Krugman, 1979; Lancaster, 1980), while the second group pays attention on the measurement of the extent of IIT (Grubel \& Lloyd, 1975). Although there have been a large number of empirical researches contributed to the determinants of IIT, most of them only pay attention on developed countries where the trade flows are similar due to similar demand structure and production technology (Łapińska, 2016). Studies on the determinants of IIT in developing countries remain modest (Ekanayake, 2001; Kien \& Thao, 2016). Until now, there is no study on intraindustry trade between Vietnam and countries in TransPacific Partnership (TPP) that Vietnam recently signed a trade agreement in early 2016. More importantly, given the quick growing of international trade between Vietnam and 
her trading partners with the introduction of TPP free trade agreement, a study of Vietnam's IIT is urgent and necessary. This study is expected to make some contribution on the evidence of developing country's IIT.

\section{An Overview of Vietnam's Intra-industry Trade}

IIT is generally measured by Grubel-Lloyd index (GL index) which expresses in the following form:

$$
I I T_{k, A B}=1-\frac{\left|X_{k, A B}-M_{k, A B}\right|}{X_{k, A B}+M_{k, A B}}
$$

where $\mathrm{X}_{\mathrm{k}}$ is export value of sector $k$, and $\mathrm{M}_{\mathrm{k}}$ is import value of sector $k$. A and B are two trading countries.

If a country simultaneously exports and imports similar types of goods and services in sector $k$, then $X_{k}=M_{k}$, and GL index equals 1 . If a country only exports or imports goods and services in sector $\mathrm{k}$, the GL index equals 0 . Thus, the intra-industry trade index takes values from 0 (pure inter-industry trade) to 1 (pure intra-industry trade).

In addition, we can calculate the weighted intra-industry trade index for each trading country by taking IIT $_{k, A B}$ multiply for the ratio of trading of country A with all the trading country for the commodity. It means that we get $\mathrm{IIT}_{\mathrm{k}, \mathrm{AB}}$ multiply for

$$
\frac{X_{k, A B}+M_{k, A B}}{\sum_{k}^{n} X_{k}+M_{k}}
$$

According to Duran and Alvarez (2008), IIT can be classified as follow:

Class 1: GL > 0.33

Intra-industry trade

Class 2: $0.10 \leq \mathrm{GL} \leq 0.33$

Potential for intra-industry trade Class 3: GL $<0.10$ Inter-industry trade

We apply the weighted intra-industry trade formula and the data from UN-Comtrade database at 6 digit level to calculate for IIT between Vietnam and countries in TPP from 2000 to 2014. It should be noted that the United States is still considered as a member of TPP in the study period of this paper. The IIT calculations are performed at the 6-digit level of disaggregation to avoid the aggregation bias. Aggregation bias occurs when different types of goods and services are grouped together in the same industry. For example, the SITC (Standard International Trade Classification) classifies the data into 10 sectors (1-digit level), and in each of these 1-digit level can be divided into 10 more categories at the 2-digit level. In turn, sectors at the 2-digit level can be divided into 10 or even more at the 3 digit level, and the division continues until the sectors reach 6 digits (more than 50,000 commodities). This study uses industry data at 6-digit level which is the most detailed level to calculate the intra-industry trade. The results of IIT would be more accurate to compare with other studies in this field.

Table 1: The Extent of IIT between Vietnam and Countries in TPP

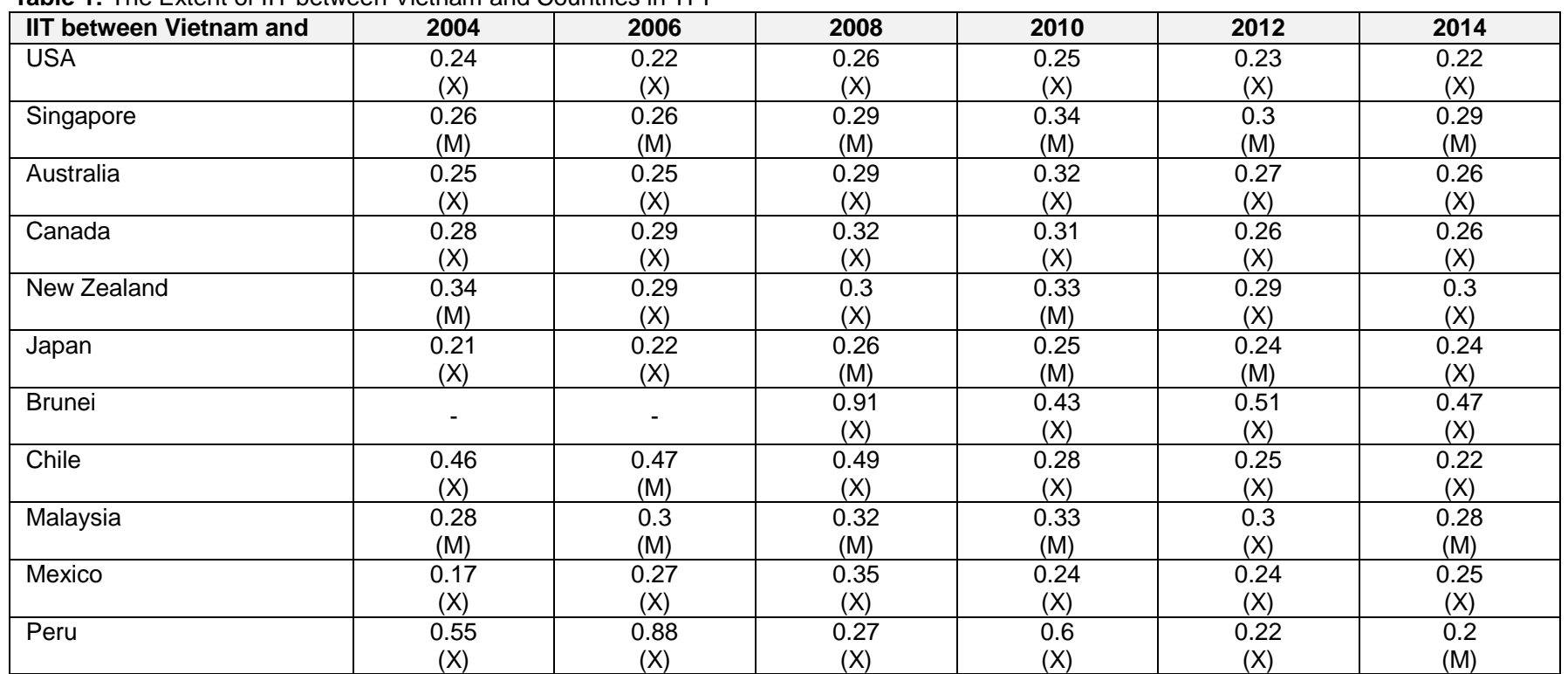

Source: Author's calculation based on data from UNCOMTRADE 2016

Note: $X$ represents the trade surplus, $M$ represents the trade deficit

Intra-industry trade often exists between developed nations since they have similar level of development and market size. Vietnam, a developing country, has been in the process industrialization and only has the comparative 
advantage in labor-intensive and low-technology products (Kien \& Thao, 2016). As a consequence, the results from table 1 show that Vietnam does not have intra-industry trade with most of countries in TPP (except Brunei, but Brunei is not an important trading partner with Vietnam). Vietnam also has the potential for intra-industry trade with only few countries such as Singapore, New Zealand, and Malaysia. One of the reasons that Vietnam has low level of intraindustry trade between TPP countries would be the lacking of advanced technology in production. The large share of country's exports is resource-intensive manufactures and agricultural commodities (Kien \& Thao, 2016).

The GL-IIT index only tells us whether the transaction between two countries is intra or inter-industry trade, but the index does not show its source from exports or imports. In order to know this source, we have to observe the trade balance. The $\mathrm{X}$ symbol in table 1 represents the countries in which Vietnam has trade surplus, and $\mathrm{M}$ represents the country in which Vietnam has trade deficit. Vietnam is a net exporter with the USA, Australia, Canada, New Zealand, Brunei, Chile, Mexico and Peru. In addition, with the high level of inter-industry trade between Vietnam and these countries demonstrates the dependence of Vietnam on these export markets. Vietnam is also net importer with some countries such as Singapore, Japan and Malaysia.

We go further by examining the intra-industry by technology level. To the best of our knowledge, our paper is the first to consider the intra-industry by technology level in Vietnam. Accordingly, the extent of IIT classification by technology level has been at a low level. Amongst trading partners in TPP, Vietnam has obtained the intra-industry trade with New Zealand in low skill and technology intensive manufactures products $(\mathrm{C})$ and resource-intensive manufactures and agricultural commodities with some countries such as Canada, Mexico, and Peru.

Table 2: IIT Classification by Technology Level

\begin{tabular}{|c|c|c|c|c|c|c|c|c|c|c|c|c|}
\hline \multirow{2}{*}{$\begin{array}{l}\text { Trading } \\
\text { partners }\end{array}$} & \multicolumn{2}{|c|}{ E } & \multicolumn{2}{|c|}{ D } & \multicolumn{2}{|c|}{ C } & \multicolumn{2}{|c|}{$\mathbf{F}$} & \multicolumn{2}{|c|}{ B } & \multicolumn{2}{|c|}{ A } \\
\hline & 2004 & 2014 & 2004 & 2014 & 2004 & 2014 & 2004 & 2014 & 2004 & 2014 & 2004 & 2014 \\
\hline USA & $\begin{array}{c}0.27 \\
{[\mathrm{M}]}\end{array}$ & $\begin{array}{c}0.19 \\
{[X]}\end{array}$ & $\begin{array}{c}0.27 \\
{[\mathrm{X}]}\end{array}$ & $\begin{array}{c}0.25 \\
{[X]}\end{array}$ & $\begin{array}{c}0.30 \\
{[\mathrm{X}]}\end{array}$ & $\begin{array}{c}0.30 \\
{[X]}\end{array}$ & $\begin{array}{c}0.18 \\
{[\mathrm{X}]}\end{array}$ & $\begin{array}{c}0.24 \\
{[\mathrm{X}]}\end{array}$ & $\begin{array}{c}0.21 \\
{[X]}\end{array}$ & $\begin{array}{c}0.16 \\
{[X]}\end{array}$ & $\begin{array}{c}0.24 \\
{[X]}\end{array}$ & $\begin{array}{c}0.20 \\
{[\mathrm{X}]}\end{array}$ \\
\hline Singapore & $\begin{array}{l}0.18 \\
{[\mathrm{M}]}\end{array}$ & $\begin{array}{l}0.27 \\
{[\mathrm{M}]}\end{array}$ & $\begin{array}{c}0.26 \\
{[\mathrm{M}]}\end{array}$ & $\begin{array}{l}0.33 \\
{[\mathrm{M}]}\end{array}$ & $\begin{array}{l}0.30 \\
{[\mathrm{M}]}\end{array}$ & $\begin{array}{l}0.33 \\
{[X]}\end{array}$ & $\begin{array}{l}0.18 \\
{[\mathrm{M}]}\end{array}$ & $\begin{array}{l}0.30 \\
{[\mathrm{M}]}\end{array}$ & $\begin{array}{l}0.29 \\
{[\mathrm{M}]}\end{array}$ & $\begin{array}{l}0.24 \\
{[X]}\end{array}$ & $\begin{array}{l}0.33 \\
{[X]}\end{array}$ & $\begin{array}{l}0.32 \\
{[\mathrm{M}]}\end{array}$ \\
\hline Australia & $\begin{array}{l}0.28 \\
{[\mathrm{M}]}\end{array}$ & $\begin{array}{l}0.28 \\
{[\mathrm{X}]}\end{array}$ & $\begin{array}{c}0.25 \\
{[\mathrm{X}]}\end{array}$ & $\begin{array}{c}0.30 \\
{[\mathrm{X}]}\end{array}$ & $\begin{array}{c}0.29 \\
{[\mathrm{X}]}\end{array}$ & $\begin{array}{c}0.30 \\
{[X]}\end{array}$ & $\begin{array}{l}0.36 \\
{[\mathrm{X}]}\end{array}$ & $\begin{array}{l}0.23 \\
{[\mathrm{X}]}\end{array}$ & $\begin{array}{c}0.19 \\
{[X]}\end{array}$ & $\begin{array}{l}0.18 \\
{[X]}\end{array}$ & $\begin{array}{c}0.22 \\
{[\mathrm{X}]}\end{array}$ & $\begin{array}{c}0.22 \\
{[\mathrm{X}]}\end{array}$ \\
\hline Canada & $\begin{array}{l}0.39 \\
{[\mathrm{M}]}\end{array}$ & $\begin{array}{l}0.27 \\
{[\mathrm{X}]}\end{array}$ & $\begin{array}{l}0.41 \\
{[\mathrm{M}]}\end{array}$ & $\begin{array}{c}0.30 \\
{[X]}\end{array}$ & $\begin{array}{c}0.27 \\
{[X]}\end{array}$ & $\begin{array}{c}0.22 \\
{[X]}\end{array}$ & $\begin{array}{c}0.17 \\
{[X]}\end{array}$ & $\begin{array}{l}0.31 \\
{[\mathrm{X}]}\end{array}$ & $\begin{array}{c}0.30 \\
{[\mathrm{X}]}\end{array}$ & $\begin{array}{c}0.19 \\
{[X]}\end{array}$ & $\begin{array}{c}0.20 \\
{[X]}\end{array}$ & $\begin{array}{l}0.28 \\
{[X]}\end{array}$ \\
\hline New Zealand & $\begin{array}{l}0.21 \\
{[\mathrm{M}]}\end{array}$ & $\begin{array}{c}0.27 \\
{[\mathrm{X}]}\end{array}$ & $\begin{array}{c}0.17 \\
{[\mathrm{X}]}\end{array}$ & $\begin{array}{c}0.30 \\
{[\mathrm{X}]}\end{array}$ & $\begin{array}{c}0.59 \\
{[\mathrm{X}]}\end{array}$ & $\begin{array}{c}0.52 \\
{[X]}\end{array}$ & $\begin{array}{l}0.22 \\
{[\mathrm{M}]}\end{array}$ & $\begin{array}{c}0.22 \\
{[\mathrm{X}]}\end{array}$ & $\begin{array}{c}0.35 \\
{[\mathrm{X}]}\end{array}$ & $\begin{array}{l}0.22 \\
{[\mathrm{M}]}\end{array}$ & $\begin{array}{c}0.83 \\
{[\mathrm{X}]}\end{array}$ & $\begin{array}{l}0.27 \\
{[\mathrm{M}]}\end{array}$ \\
\hline Japan & $\begin{array}{l}0.21 \\
{[\mathrm{M}]}\end{array}$ & $\begin{array}{l}0.23 \\
{[\mathrm{M}]}\end{array}$ & $\begin{array}{c}0.23 \\
{[\mathrm{M}]}\end{array}$ & $\begin{array}{l}0.27 \\
{[\mathrm{M}]}\end{array}$ & $\begin{array}{l}0.21 \\
{[\mathrm{M}]}\end{array}$ & $\begin{array}{l}0.30 \\
{[\mathrm{M}]}\end{array}$ & $\begin{array}{l}0.18 \\
{[X]}\end{array}$ & $\begin{array}{l}0.25 \\
{[\mathrm{X}]}\end{array}$ & $\begin{array}{c}0.19 \\
{[X]}\end{array}$ & $\begin{array}{c}0.18 \\
{[X]}\end{array}$ & $\begin{array}{c}0.24 \\
{[X]}\end{array}$ & $\begin{array}{c}0.22 \\
{[X]}\end{array}$ \\
\hline Brunei & - & - & - & $\begin{array}{l}0.41 \\
{[\mathrm{M}]}\end{array}$ & - & - & - & - & - & - & - & - \\
\hline Chile & - & $\begin{array}{l}0.3 \\
{[X]}\end{array}$ & $\begin{array}{c}0.47 \\
{[X]}\end{array}$ & $\begin{array}{c}0.18 \\
{[X]}\end{array}$ & - & $\begin{array}{c}0.25 \\
{[X]}\end{array}$ & - & $\begin{array}{c}0.25 \\
{[X]}\end{array}$ & $\begin{array}{l}0.86 \\
{[\mathrm{M}]}\end{array}$ & $\begin{array}{c}0.24 \\
{[X]}\end{array}$ & $\begin{array}{c}0.04 \\
{[\mathrm{M}]}\end{array}$ & $\begin{array}{c}0.83 \\
{[X]}\end{array}$ \\
\hline Malaysia & $\begin{array}{l}0.28 \\
{[\mathrm{M}]}\end{array}$ & $\begin{array}{l}0.30 \\
{[\mathrm{M}]}\end{array}$ & $\begin{array}{l}0.32 \\
{[\mathrm{M}]}\end{array}$ & $\begin{array}{l}0.29 \\
{[\mathrm{M}]}\end{array}$ & $\begin{array}{c}0.28 \\
{[X]}\end{array}$ & $\begin{array}{l}0.30 \\
{[X]}\end{array}$ & $\begin{array}{c}0.10 \\
{[X]}\end{array}$ & $\begin{array}{l}0.33 \\
{[\mathrm{M}]}\end{array}$ & $\begin{array}{c}0.27 \\
{[\mathrm{X}]}\end{array}$ & $\begin{array}{c}0.27 \\
{[X]}\end{array}$ & $\begin{array}{c}0.28 \\
{[X]}\end{array}$ & $\begin{array}{c}0.29 \\
{[X]}\end{array}$ \\
\hline Mexico & $\begin{array}{c}0.48 \\
{[\mathrm{X}]}\end{array}$ & $\begin{array}{c}0.32 \\
{[\mathrm{X}]}\end{array}$ & - & $\begin{array}{c}0.24 \\
{[X]}\end{array}$ & - & $\begin{array}{c}0.47 \\
{[\mathrm{X}]}\end{array}$ & $\begin{array}{c}0.09 \\
{[X]}\end{array}$ & $\begin{array}{c}0.04 \\
{[\mathrm{X}]}\end{array}$ & $\begin{array}{c}0.03 \\
{[\mathrm{X}]}\end{array}$ & $\begin{array}{c}0.19 \\
{[\mathrm{X}]}\end{array}$ & $\begin{array}{c}0.10 \\
{[\mathrm{X}]}\end{array}$ & $\begin{array}{c}0.14 \\
{[X]}\end{array}$ \\
\hline Peru & - & - & - & $\begin{array}{c}0.02 \\
{[X]}\end{array}$ & - & - & - & - & - & $\begin{array}{c}0.21 \\
{[\mathrm{X}]}\end{array}$ & $\begin{array}{c}0.55 \\
{[X]}\end{array}$ & $\begin{array}{l}0.28 \\
{[\mathrm{M}]}\end{array}$ \\
\hline
\end{tabular}

Source: Author's calculation based on data from UNCOMTRADE 2016

Note: According to UNCOMTRADE classification, E: high skill and technology intensive manufactures; $D$ : medium skill and technology intensive manufactures; C: low skill and technology intensive manufactures; A: non-fuel primary commodities; B: resource-intensive manufactures; F: mineral fuels.

\section{Briefs of Literature Review}

Previous theoretical and empirical studies classified the determinants of intra-industry trade into two groups: country-specific studies and industry-specific studies (Greenaway, Hine, \& Milner, 1995; Balassa \& Bauwens, 1987; Greenaway \& Milner, 1986). Country-specific studies explain IIT through macroeconomic variables including GDP, per capita income, dissimilarity in income, distance, trade openness. The industry-specific studies explain the determinants of IIT through industry-specific variables such as firm concentration ratio, marketing costs, economy of scale.
Previous empirical works on IIT in Vietnam are very limited. Until now, there are only a few researches on this field. In the groundbreaking empirical work, Kien and Thao (2016) conduct a study about the determinants of IIT in manufacturing industry between Vietnam and her major trading countries. By employing panel data from 2000 to 2013, authors firstly utilize the GL index to calculate IIT. IIT is also decomposed into horizontal intra-industry trade (HIIT) and vertical intra-industry trade (VIIT). To get some sense of the factors which affect IIT, they include variables such as the average economic size, the average per capita income, the difference in income levels, distance, trade imbalance, and free trade agreements. They find expected 
results: average country size and average income are positively associated with Vietnam's IIT, while income inequality, distance, and trade imbalance are negative related with IIT. A problem to this paper is that the authors employ 2-digit SITC levels of aggregation to calculate the IIT and 4digit data level to compute HIIT and VIIT. The calculation of IIT at aggregation level of data can lead to the aggregation bias. Aggregation bias occurs when different types of goods and services are grouped together in the same industry. In order to avoid this bias, we need to perform the data in most detailed form.

\section{Determinants of IIT in Vietnam}

\subsection{Model Specification}

To examine the possible determinants of intra-industry trade between Vietnam and countries in TPP, we propose the following model:

$$
\begin{aligned}
\mathbf{I I T}_{\mathrm{kAB}}= & \mathbf{f}\left(\mathbf{G D P}_{\mathrm{B}}, \mathrm{DPCI}_{\mathrm{AB}}, \mathbf{P C I}_{\mathrm{B}}, \mathrm{DIST}_{\mathrm{AB}}, \mathrm{OPEN}_{\mathrm{AB}},\right. \\
& \text { RER } \left._{\mathrm{AB}}, \mathrm{FDI}_{\mathrm{AB}}\right)
\end{aligned}
$$

where k represents the industry.

A is the trading country which is Vietnam.

$\mathrm{B}$ is the trading partners which are other 11 countries in the TPP.

We use a log-linear function to estimate the determinants of IIT. This model allows us to interpret the result of estimated coefficients in terms of elasticity and make the estimates less sensitive to extreme observations (Mulenga, 2012). The IIT model is specified as follows:

$$
\begin{aligned}
& \log \mathrm{IIT}_{\mathrm{kAB}}=\beta_{0}+\beta_{1} \log \mathrm{GDP}_{\mathrm{B}}+\beta_{2} \operatorname{logDPCI} \mathrm{I}_{\mathrm{AB}}+\beta_{3} \log \mathrm{PCI}_{\mathrm{B}}+ \\
& \beta_{4} \log \text { IST }_{\mathrm{AB}}+\beta_{5} \log \mathrm{OPEN}_{\mathrm{AB}}+\beta_{6} \operatorname{logRER} \mathrm{R}_{\mathrm{AB},+} \\
& \beta_{7} \log \mathrm{FDI}_{\mathrm{AB}}+\varepsilon_{\mathrm{AB}}
\end{aligned}
$$

- $\quad$ IIT $_{\mathrm{kAB}}$ is intra industry trade between Vietnam and trading partner B, IIT is the dependent variable in this study.

- $\mathrm{GDP}_{\mathrm{B}}$ is gross domestic product of country B.

- $\mathrm{DPCI}_{\mathrm{AB}}$ is the dissimilarity in per capita income between Vietnam and country $B$.

- $\quad \mathrm{PCI}_{\mathrm{B}}$ is per capita income of country $\mathrm{B}$.

- DIST $_{\mathrm{AB}}$ is the physical distance between the capital of Vietnam and country $\mathrm{B}$.

- $\mathrm{OPEN}_{\mathrm{AB}}$ is the openness index

- $\mathrm{RER}_{\mathrm{AB}}$ is the real exchange rate between Vietnam and trading partner $\mathrm{B}$.

- $\mathrm{FDI}_{\mathrm{AB}}$ is foreign direct investment of the Vietnam with its trading partners.

\subsection{Hypotheses}

Basing on previous empirical research, this part aims to develop hypotheses relating to country-specific factors to investigate the possible determinants of intra-industry trade.

Hypothesis 1: GDP of the trading partners has a positive correlation with intra-industry trade.

GDP is an indicator to measure the economic performance of a country. It is a proxy for market size. Countries with large market size tend to have the potential to produce diversified products thanks to the economies of scale (Ekanayake, 2001). There is also higher demand of diversified foreign products in these economies. In the empirical analysis, Filippini (2003) finds the evidence that intra-industry trade will enhance in the economy with larger size. In this study, GDP is measured by real GDP at constant 2005 prices, in US dollars.

Hypothesis 2: The higher the dissimilarity in per capita income, the lower the intra-industry trade

Balassa and Bauwens (1987) state that the difference in per capita income reflects the difference in demand structure. Countries with similar level of income will have similar demand structure. This similarity will stimulate the production of similar but differentiated products and trade with other countries. Following Mulenga (2012), the difference in per capita income between Vietnam and a trading country is measured as:

$$
\mathrm{DPCI}_{\mathrm{AB}}=\left|\mathbf{P C I}_{\mathrm{A}}-\mathbf{P C I}_{\mathrm{B}}\right|
$$

where,

$\mathrm{DPCI}_{\mathrm{AB}}$ is dissimilarity in per capita income between Vietnam and partner country $B$.

$\mathrm{PCI}_{\mathrm{A}}$ is the PCI for Vietnam.

$\mathrm{PCI}_{\mathrm{B}}$ is the PCI of the partner country.

Hypothesis 3: The greater the per capita income, the higher the intra-industry trade

Intra-industry between a country and its trading partner tends to larger as per capita income of the partner is higher. In countries with higher income, the demand structure will be more complex and different. It is contrast with countries lower level of PCI, the demand of customers is not large and relatively standardized with characteristics of the product (Ekanayake, 2001). In this study, PCI is measured by the real PCI at constant 2005 prices and in US dollars.

Hypothesis 4: The higher the geographical distance between Vietnam and trading partners in TPP, the lower the intraindustry trade.

Geographical distance acts as a natural barrier to 
international trade. When the distance between two countries is larger, it incurs trade costs such as transportation and information costs (Balassa \& Bauwens, 1987). Krugman (1979, 1980) pointed out that the higher the transportation cost, the trade volume (including intra-industry trade and inter-industry trade) is lower. Geographical closeness stimulates the volume of IIT. This is because countries close to each other usually have similar production structure and demand structure than countries with geographically far away. Geographical distance is measured by the distance from the capital of Vietnam to the capital of the trading partners in TPP.

Hypothesis 5: The higher the openness to trade between Vietnam and trading partners, the greater the IIT.

Trade openness represents for degree of trade between the two countries. When trade volume increases, there will be greater opportunities for more diversified products to be exchanged. The theory of IIT proposed by Krugman (1981), Krugman (1991) and Venables (1985) shows that the level of product differentiation tends to higher when trade volume is higher. The openness of the country is measured by the formula:

$$
\mathrm{OPEN}_{\mathrm{AB}}=\frac{X_{A B}+M_{A B}}{G D P_{A}}
$$

in which:

$\mathrm{X}_{\mathrm{AB}}$ : exports of Vietnam (country A) to country B

$M_{A B}$ : imports of Vietnam (country A) from country $B$

$\mathrm{GDP}_{\mathrm{A}}$ : gross domestic product of Vietnam (country A)

Hypothesis 6: The real exchange rate is negatively correlated with IIT

Empirical studies in the gravity model have shown that real exchange rates are very important in explaining the changes in trade between nations. Real exchange rate is expected to have negative impacts on IIT since an appreciation of Vietnam Dong would make export products more expensive and import products cheaper for domestic citizens (Mulenga, 2012).

The real exchange rate between two countries is calculated by the nominal exchange rate multiplies by the GDP deflator. The formula of real exchange rate as follow:

$$
\mathrm{RER}_{\mathrm{AB}}=\mathrm{E}_{\mathrm{AB}} \times \frac{P_{B}}{P_{A}}
$$

$\mathrm{RER}_{\mathrm{AB}}$ : the real exchange rate between Vietnam (country A) and the other countries in TPP (country B).

$\mathrm{E}_{\mathrm{AB}}$ : the nominal exchange rate of Vietnam (country $\mathrm{A}$ ) and the other countries in TPP (country B). Nominal exchange rate is defined as the number of domestic currencies per unit of foreign currency.
$\mathrm{P}_{\mathrm{A}}$ : GDP deflator of Vietnam (country A).

$\mathrm{P}_{\mathrm{B}}$ : GDP deflator of other countries in TPP.

Hypothesis 7: There is a positive correlation between FDI and IIT

When multinational corporations invest in the host country to take advantage of factors of production, the final products then are exported back to the home country (Sawyer, Sprinkle, \& Tochkov, 2010). Hence, we expect that foreign direct investment promotes intra-industry trade. In this paper, we add the net inflows of FDI to account for the role of export-oriented FDI in Vietnam.

\subsection{Method of Estimation and Data Sources}

Panel data regression technique was chosen to analyze the factors affecting intra-industry trade. Both of the fixed effect and random effect model are employed. Hausman test is used choose the appropriate model. The use of panel data has many advantages over cross section data or time series data. First, we have more degree of freedom, so the efficiency of econometric estimation will be improved. Second, the problems of multicollinearity as well as autocorrelation are likely less serious in panel data. Third, panel data allows us to control for the problems of unobserved variables which are correlated with dependent variables. Hence, the danger of omitted variable bias will be reduced.

The sample contains 11 countries in TPP as the trading partners with Vietnam. Trade data are collected from the UN COMTRADE database. The net inflows of FDI are collected from Vietnam's Ministry of Planning and Investment. Geographical distances between Vietnam and trading partner are obtained from the website (http://indo.com/distance/). Other data of country's characteristics and trade such as GDP, per capita income, nominal exchange rate, and GDP deflator are derived from the World Development Indicators of World Bank (http://databank.worldbank.org).

\subsection{Empirical Results and Discussion}

Table 3 reports the results of the determinants of IIT. It is important to note that in cross-country regression, heteroskedasticity may be a serious problem that we may face with. In order to overcome heteroskedasticity, white heteroskedasticity consistent covariance matrix is employed for each standard error of coefficient. In addition, VIF (variance inflation factor) test also provides no evidence of multicollinearity in the model. Hausman test confirms that fixed effect model is more appropriate than random effect model. 
Table 3: Panel Data Regression for the Determinants of IIT Dependent Variable: IIT in the 2000-2014 period

\begin{tabular}{|c|c|c|c|c|}
\hline \multirow{2}{*}{$\begin{array}{l}\text { Explanatory } \\
\text { Variables }\end{array}$} & (1) & (2) & (3) & (4) \\
\hline & Fixed effects & Fixed effects & Random effects & Random effects \\
\hline Constant & $\begin{array}{c}-7.8 \\
(5.797494)\end{array}$ & $\begin{array}{c}-10.05 \\
(6.633546)\end{array}$ & $\begin{array}{c}-.87 \\
(1.102498)\end{array}$ & $\begin{array}{c}-.896 \\
(1.067252)\end{array}$ \\
\hline LogGDP & $\begin{array}{c}1.04^{* *} \\
(.3476517)\end{array}$ & $\begin{array}{c}1.230^{* *} \\
(.483968)\end{array}$ & $\begin{array}{c}.007 \\
(.0506723)\end{array}$ & $\begin{array}{c}.006 \\
(.0507317)\end{array}$ \\
\hline LogOpenness & $\begin{array}{c}-0.13^{\star *} \\
(.0552747)\end{array}$ & $\begin{array}{c}-0.11^{* * *} \\
(.0568622)\end{array}$ & $\begin{array}{l}-0.10^{\star *} \\
(.04612)\end{array}$ & $\begin{array}{c}-0.105^{\star *} \\
(.0455144)\end{array}$ \\
\hline LogFDI & $\begin{array}{c}0.041 \\
(.0238732)\end{array}$ & $\begin{array}{c}0.040 \\
(.0245975)\end{array}$ & $\begin{array}{c}-.009 \\
(.0199878)\end{array}$ & $\begin{array}{c}-.010 \\
(.0200382)\end{array}$ \\
\hline LogRER & $\begin{array}{c}-0.11 \\
(.0954245) \\
\end{array}$ & $\begin{array}{c}-0.14 \\
(.0911102) \\
\end{array}$ & $\begin{array}{c}.014^{* *} \\
(.0104885) \\
\end{array}$ & $\begin{array}{c}.014 \\
(.0105992) \\
\end{array}$ \\
\hline LogDPCl & $\begin{array}{c}-2.30^{*} \\
(.5352622)\end{array}$ & & $\begin{array}{c}.026 \\
(.0405514)\end{array}$ & \\
\hline LogPCl & & $\begin{array}{c}-2.53^{*} \\
(.7954799)\end{array}$ & & $\begin{array}{c}.031 \\
(.0456037)\end{array}$ \\
\hline LogDistance & & & $\begin{array}{c}-.13^{\star *} \\
(.058324)\end{array}$ & $\begin{array}{c}-.12^{\star *} \\
(.0582613)\end{array}$ \\
\hline No. of obs & 138 & 138 & 138 & 138 \\
\hline Adjusted $\mathrm{R}^{2}$ & 0.0064 & 0.0192 & 0.2130 & 0.2139 \\
\hline
\end{tabular}

Note: ${ }^{*}$ denotes significant at $1 \%,{ }^{* *}$ denotes significant at $5 \%,{ }^{* * *}$ denotes significant at $10 \%$

Heteroskedastic panel corrected standard errors are reported in brackets

GDP variable comes to the equation with positive sign and statistically significant at $5 \%$ level. This can be explained that the larger economic size, the larger the extent of IIT. Owning larger economic size, countries in TPP would have higher opportunity to produce differentiated goods under economies of scale, and these countries also have higher demand for differentiated goods from Vietnam, leading to higher IIT. This finding is in line with other studies such as Ekanayake (2001), Ha, Ngoc and Duc (2019), and Mulenga (2012). The hypothesis 1 is verified.

The Openness coefficient is negative and statistically significant at 5\%. This result implies that the higher the openness of Vietnam and her trading partners, the lower the degree of intra-industry trade. This is explained that countries in TPP will focus on producing and exporting commodities for which they have a comparative advantage and they import goods and services that they have higher cost of production.

DPCI variable is negative as expected and statistically significant at $1 \%$. This result shows that the lower the difference of per capita income between the trading nations, the higher the intra-industry trade and vice versa. When countries have similar income level, they will have similar demand for consumption and thus stimulate exchange of diversification products. This result is similar to the study of Ekanayake (2001) for Mexico.

In model 2, we also include PCI variable to measure the level of development of a country. PCI coefficient has a negative sign and statistically significant at $1 \%$. This result indicates that the greater the PCI, the lower the extent of IIT. The finding is different from our expectation. PCI may explain for trade based on comparative advantage as different from IIT. Our finding is consistent with the results of Mulenga (2012) for Zambia.

The variables FDI and RER proved to be statistically insignificant. Therefore, the hypothesis 6 and 7 failed to be verified. Possible explanation for the insignificant impacts of FDI inflows is that when a FDI project is started, it needs time to construct the factory, buy machine, and produce goods and services. After 3 or 4 years since the project is started we could see it effects on IIT. In addition, with the strong efforts of Vietnam's government to stabilize the exchange rate, this could make RER has no effect on IIT.

Geographical distance variable enters equation with negative sign and statistically significant at 5\% level. The result implies that, all other thing being equal, one percent increase in the distance is associated with a decrease 0.12 in IIT. The result is parallel with the finding obtained by Kien and Thao (2016) who suggest that physical distance is a proxy for transportation and information cost. Countries with close proximity have chance to reduce these costs and strengthen the IIT. In addition, the close distance between countries would allow them to share similar demand structure and culture, and thus encourage IIT.

\section{Conclusion}

Together with the trend of globalization and international integration has strongly occurred in the world, Vietnam has officially joined the Trans-pacific Partnership Trade Agreement (TPP) in 2016. Joining the TPP has opened up many opportunities as well as challenges for Vietnam. As intra-industry trade is recognized to have potential benefits to improve the economic prospects for the country, the purpose of this study is to measure the extent of IIT between Vietnam and her trading partners in TPP and also investigate the determinants of this trade. The study is expected to make the modest contribution on the evidence of developing country's IIT. In the empirical analysis, the results from 
panel data regression indicate that Vietnam's intra-industry trade is positively correlated with country size, while it is negatively correlated with income dissimilarity, the trade openness, and geographical distance.

\section{References}

Balassa, B., \& Bauwens, L. (1987). Intra-industry specialisation in a multi-country and multi-industry framework. The Economic Journal, 97(388), 923-939.

Duran, J., \& Álvarez, A. (2008). Indicadores de comercio exteriory política comercial: medidores de posicióny dinamismo comercial. CEPAL, Santiago de Chile.

Ekanayake, E. M. (2001). Determinants of trade: The case of Mexico. The International Trade Journal, 15(1), 89-112.

Filippini, C., \& Molini, V. (2003). The determinants of East Asian trade flows: A gravity equation approach. Journal of Asian Economics, 14(5), 695-711.

Greenaway, D., \& Milner, C. (1986). The Economics of intra-industry trade. New York: Basil Blackwell Ltd.

Greenaway, D., Hine, R., \& Milner, C. (1994). Countryspecific factors and the pattern of horizontal and vertical intra-industry trade in the UK. Weltwirtschaftliches Archiv, 130(1), 77-100.

Greenaway, D., Hine, R., \& Milner, C. (1995). Vertical and horizontal intra-industry trade: A cross industry analysis for the United Kingdom. The Economic Journal, 105(433), 1505-1518.

Grubel, H. G., \& Lloyd, P. J. (1975). Intra-industry trade: The theory and measurement of international trade in differentiated products. London, UK: Macmillan Press.

Ha, M. N., Ngoc, H. B., \& Duc, H. V. (2019). The nexus between economic integration and growth: Application to Vietnam. Annals of Financial Economics, 14(3), 1-16. http://www.worldscientific.com/doi/abs/10.1142/S20104
95219500143

Kien, T. N., \& Thao, T. T. P. (2016). Determinants of intraindustry trade for Vietnam's manufacturing industry. Journal of Economics and Development, 18(1), 5-18.

Krugman, P. (1980). Scale economies, product differentiation, and the pattern of trade. The American Economic Review, 70(5), 950-959.

Krugman, P. R. (1979). Increasing returns, monopolistic competition, and international trade. Journal of International Economics, 9(4), 469-479.

Krugman, P. R., (1981), Intra-industry specialization and gains from trade. Journal of Political Economy, 89, 959973.

Krugman, P. R., (1991), Increasing returns and economic geography. Journal of Political Economy, 99, 483-499.

Lancaster, K. (1980). Intra-industry trade under perfect monopolistic competition. Journal of International Economics, 10(2), 151-175.

Łapińska, J. (2016). Determinant factors of intra-industry trade: The case of Poland and its European Union trading partners. Equilibrium. Quarterly Journal of Economics and Economic Policy, 11(2), 251-264.

Mulenga, M. C. (2012). Determinants of intra-industry trade between Zambia and it's trading partners in the Southern African Development Community (SADC). Ethiopian Journal of Economics, 21(1), 107-132.

Sawyer, W. C., Sprinkle, R. L., \& Tochkov, K. (2010). Patterns and determinants of intra-industry trade in Asia. Journal of Asian Economics, 21(5), 485-493.

Venables, A. J. (1985), Trade and trade policy with imperfect competition: The case of identical products and free entry. Journal of International Economics, 19, 1-19.

Zhang, Y., \& Clark, D. P. (2009). Pattern and determinants of United States' intra-industry trade. The International Trade Journal, 23(3), 325-356. 